\title{
A review of the catfish genus Pterocryptis (Siluridae) in Vietnam, with the description of two new species
}

\author{
H. H. NG*广ף AND J. FREYHOF \\ *Fish Division, Museum of Zoology, University of Michigan, 1109 Geddes Avenue, \\ Ann Arbor, Michigan 48109-1079, U.S.A., †Department of Biological Sciences, \\ National University of Singapore, 10 Kent Ridge Crescent, Singapore 119260 and \\ $\$$ Institut für Gewässerökologie und Binnenfischerei, Müggelseedamm 310, \\ D-12561 Berlin, Germany
}

(Received 9 December 2000, Accepted 23 May 2001)

\begin{abstract}
Of the silurid catfish genus Pterocryptis in Vietnam, a total of four species are recognized as valid, of which Pterocryptis crenula and $P$. verecunda are described here as new. The type locality of $P$. cochinchinensis is restricted to central Vietnam, and the species is redescribed from topotypic material. Pterocryptis crenula (from northeastern Vietnam) can be differentiated from its congeners in having visibly confluent anal and caudal fins while $P$. verecunda (from Cat $\mathrm{Ba}$ Island in northeastern Vietnam) can be differentiated from its congeners in having the genital papilla concealed behind the anus. Notes on the identity of other nominal Pterocryptis species are also provided.

(C) 2001 The Fisheries Society of the British Isles
\end{abstract}

Key words: new species; taxonomy; Siluridae; Pterocryptis.

\section{INTRODUCTION}

Silurid catfishes of the genus Pterocryptis Peters, 1861, are usually found in relatively fast-flowing mountain streams throughout India, southern China and South-east Asia. The genus was recently removed from synonymy with Silurus Linnaeus, 1758, by Bornbusch (1991), and the taxonomy of many of its species has not been fully resolved. There are currently 14 nominal species of Pterocryptis, of which only $P$. cochinchinensis (Valenciennes, in Cuvier \& Valenciennes, 1839) and P. cucphuongensis (Mai, 1978) have been reported from Vietnam (Mai, 1978).

The need for the clarification of the validities of the nominal Vietnamese Pterocryptis prompted this study, which provides a brief synopsis of the current understanding of Vietnamese Pterocryptis taxonomy.

\section{MATERIALS AND METHODS}

Measurements were made with a dial calliper and data recorded to $0 \cdot 1 \mathrm{~mm}$. Counts and measurements were made on the left side of the specimens when possible. In tables and text, sub-units of the head are presented as proportions of head length $\left(L_{\mathrm{H}}\right)$. Head length and measurements of body parts are given as proportions of standard length $\left(L_{\mathrm{S}}\right)$.

The measurements and terminologies follow those of $\mathrm{Ng}(1999 a)$. Drawings of the specimens were made with a Nikon SMZ-10 microscopic camera lucida. The material

TAuthor to whom correspondence should be addressed. Tel.: +1 734647 2192; fax: +1 734763 4080; email: heokheen@umich.edu 


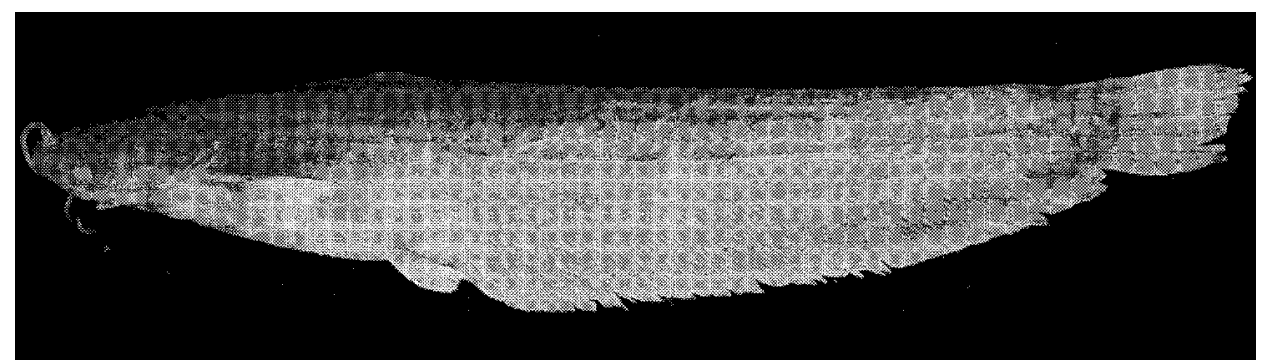

FIG. 1. Pterocryptis cochinchinensis, AMNH 231001, $96 \cdot 7 \mathrm{~mm} L_{\mathrm{S}}$; Vietnam: Quang Nam province, Tranh River.

examined in this study is deposited in the following collections: AMNH, American Museum of Natural History, New York; AMS, Australian Museum, Sydney; BMNH, Natural History Museum, London; CAS, California Academy of Sciences, San Francisco; CMK, collection of Maurice Kottelat, Cornol; MNHN, Museum National d'Histoire Naturelle, Paris; NRM, Naturhistoriska Riksmuseet, Stockholm; UMMZ, Museum of Zoology, University of Michigan, Ann Arbor; USNM, National Museum of Natural History, Washington DC; ZFMK, Zoologisches Forschunginstitut und Museum Alexander Koenig, Bonn; ZMUH, Zoology Museum, University of Hanoi; ZRC, Zoological Reference Collection, Raffles Museum of Biodiversity Research, National University of Singapore; and ZSI, Zoological Survey of India, Calcutta.

\section{RESULTS}

PTEROCRYPTIS COCHINCHINENSIS (VALENCIENNES, IN CUVIER \& VALENCIENNES, 1839) (Fig. 1)

Silurus Cochinchinensis Valenciennes, in Cuvier \& Valenciennes, 1839: 352 (type locality: Cochinchine).

Silurus cochinchinensis_-Günther, 1864: 34; Haig, 1952: 99 (in part); Serov, 1994a: 24; 1994b: 65.

Parasilurus cochinchinensis-Orsi, 1974: 161; Mai, 1978: 243, fig. 111; Nguyen, 1999: 31.

\section{Material examined}

MNHN 573, 1 ex., syntype, $115.4 \mathrm{~mm} L_{\mathrm{S}}$; MNHN B.602, 1 ex., syntype, 93.6 mm $L_{S}$; Vietnam. AMNH 227874, 2 ex., 146.9-200.6 mm $L_{S}$; Vietnam: Ha Tinh province, Trai Xay, Ke-Go Natural Reserve, stream named Libi, from mouth at impoundment lake to $c .1$ mile upstream, $18^{\circ} 7^{\prime} 34^{\prime \prime} \mathrm{N}$; $105^{\circ} 57^{\prime} 30^{\prime \prime} \mathrm{E}$. AMNH 227887, 1 ex., 114.3 mm $L_{S}$; Vietnam: Ha Tinh province, Trai Xay, Ke-Go natural reserve, stream named Mon, from mouth at impoundment lake to forest, $18^{\circ} 7^{\prime} \mathrm{N}$; $105^{\circ} 57^{\prime} \mathrm{E}$. AMNH 227902, 1 ex., $144.5 \mathrm{~mm} L_{\mathrm{S}}$; Vietnam: Quang Binh province, Minh Hoa district, Cha Lo frontier station, streams near station, $17^{\circ} 42^{\prime} \mathrm{N}$; $105^{\circ} 46^{\prime} \mathrm{E}$. AMNH 227959, 1 ex., $66.3 \mathrm{~mm} L_{\mathrm{S}}$; Vietnam: Ha Tinh province, Huong Son district, Roa An region, small stream behind base camp, tributary to main stream, $18^{\circ} 22^{\prime} \mathrm{N}$; $105^{\circ} 13^{\prime} \mathrm{E}$. AMNH 227972, 1 ex., $183.5 \mathrm{~mm} L_{\mathrm{S}}$; Vietnam: Ha Tinh province, Huong Son district, Roa An region, $18^{\circ} 22^{\prime} \mathrm{N}$; $105^{\circ} 13^{\prime} \mathrm{E}$. AMNH 227988, 2 ex., 59.8-65.5 mm $L_{\mathrm{S}}$; Vietnam: Ha Tinh province, Huong Son district, Roa An region, backwater below camp 2 (across main stream from base camp), $18^{\circ} 22^{\prime} \mathrm{N}$; $105^{\circ} 13^{\prime} \mathrm{E}$. AMNH 230993, 2 ex., 
$115 \cdot 0-125 \cdot 0 \mathrm{~mm} L_{\mathrm{S}}$; Vietnam: Quang Nam province, Tam Ky district, Nuoc Ta River, waterfall upstream from camp, $15^{\circ} 14^{\prime} \mathrm{N} 108^{\circ} 4^{\prime} \mathrm{E}$. AMNH 230994, 1 ex., $149.4 \mathrm{~mm} L_{\mathrm{S}}$; Vietnam: Quang Nam province, Tam Ky district, Nuoc Ta River, pool under bridge upstream from camp, $15^{\circ} 14^{\prime} \mathrm{N} ; 108^{\circ} 4^{\prime} \mathrm{E}$. AMNH 230995, 1 ex., $77.7 \mathrm{~mm} L_{\mathrm{S}}$; AMNH 230996, 1 ex., $61.2 \mathrm{~mm} L_{\mathrm{S}}$; Vietnam: Quang Nam province, Tam Ky district, Nuoc Ta River at ferry, $15^{\circ} 14^{\prime} 46^{\prime \prime} \mathrm{N}$; $108^{\circ} 6^{\prime} 6^{\prime \prime} \mathrm{E}$. AMNH 230999, 1 ex., 97.8 $\mathrm{mm} L_{\mathrm{S}}$; Vietnam: Quang Nam province, Tam Ky district, stream to Nam Nim River, crossing road $0.25 \mathrm{~km}$ upstream from camp, $15^{\circ} 13^{\prime} 46^{\prime \prime} \mathrm{N}$; $108^{\circ} 5^{\prime} 43^{\prime \prime} \mathrm{E}$. AMNH 231000, 1 ex., $62.0 \mathrm{~mm} L_{\mathrm{S}}$; Vietnam: Quang Nam province, Tam Ky district, stream to Nam Nim River, at camp, $0.25 \mathrm{~km}$ from camp, $15^{\circ} 13^{\prime} 3^{\prime \prime} \mathrm{N} ; 108^{\circ} 5^{\prime} 42^{\prime \prime} \mathrm{E}$. AMNH 231001, 3 ex., $96 \cdot 7-128 \cdot 1 \mathrm{~mm} L_{\mathrm{S}}$; AMNH 231002, 1 ex., 49.9 $\mathrm{mm} L_{\mathrm{S}}$; Vietnam: Quang Nam province, Tam Ky district, Tranh River, $15^{\circ} 18^{\prime} \mathrm{N}$; $108^{\circ} 7^{\prime} \mathrm{E}$. AMNH 231003, 2 ex., $56 \cdot 8-71.6 \mathrm{~mm} L_{\mathrm{S}}$; AMNH 231004, 2 ex., 88.5-123.7 mm $L_{\mathrm{S}}$; Vietnam: Quang Nam province, Tam Ky district, stream to Tranh River, $0 \cdot 25 \mathrm{~km}$ from bridge, $15^{\circ} 18^{\prime} \mathrm{N} ; 108^{\circ} 7^{\prime} \mathrm{E}$. UMMZ 238032, 1 ex., 90.8 mm $L_{\mathrm{S}}$; ZFMK 32396, 1 ex., $72 \cdot 3 \mathrm{~mm} L_{\mathrm{S}}$; Vietnam: $\mathrm{Ha}$ Tinh province, stream named Rao Mac at Son Kim, $18^{\circ} 26^{\prime} 14 \cdot 4^{\prime \prime} \mathrm{N}$; $105^{\circ} 14^{\prime} 21 \cdot 6^{\prime \prime}$ E. UMMZ 238033, 1 ex., $163 \cdot 0 \mathrm{~mm} L_{\mathrm{S}}$; Vietnam: Quang Nam province, stream $20 \mathrm{~km}$ west of Da Nang, $16^{\circ} 6^{\prime} 27 \cdot 6^{\prime \prime} \mathrm{N} ; 108^{\circ} 4^{\prime} 15^{\prime \prime} \mathrm{E}$. ZFMK 32375-32378, 4 ex., 56.6-107.6 mm $L_{\mathrm{S}}$; ZRC 46320, 3 ex., 118.9-138.0 mm $L_{\mathrm{S}}$; Vietnam: Thua Thien Hue province, stream named Suoi Voi at Thua Luu, $55 \mathrm{~km}$ south of Hue, $16^{\circ} 14^{\prime} 34 \cdot 8^{\prime \prime} \mathrm{N} ; 107^{\circ} 59^{\prime} 23 \cdot 4^{\prime \prime}$ E. ZFMK 32384, 1 ex., $76 \cdot 1 \mathrm{~mm} L_{\mathrm{S}}$; ZRC 46321, 1 ex., 68.3 $\mathrm{mm} L_{\mathrm{S}}$; Vietnam: Binh Dinh province, Song An Lao at An Lao, $14^{\circ} 36^{\prime} 9^{\prime \prime} \mathrm{N}$; $108^{\circ} 54^{\prime} 5 \cdot 4^{\prime \prime}$ E. ZFMK 29914-29916, 3 ex., 66.7-92.8 mm $L_{\mathrm{S}}$; Vietnam: Quang Tri province, Song Cam Lo about $20 \mathrm{~km}$ west of Dong Ha; $16^{\circ} 47^{\prime} 0^{\prime \prime} \mathrm{N}$; $106^{\circ} 53^{\prime} 51 \cdot 6^{\prime \prime}$ E. ZFMK 30078, 1 ex., $115 \cdot 9 \mathrm{~mm} L_{\mathrm{S}}$; Vietnam: Thua Thien Hue province, stream named Xuan Loc about $25 \mathrm{~km}$ south of Hue; $16^{\circ} 15^{\prime} 59 \cdot 4^{\prime \prime} \mathrm{N}$; $107^{\circ} 42^{\prime} 17 \cdot 4^{\prime \prime} \mathrm{E}$. ZFMK 30339, 1 ex., $72 \cdot 5 \mathrm{~mm} L_{\mathrm{S}}$; Vietnam: Thua Thien Hue province, stream named Mau about $30 \mathrm{~km}$ west of Hue; $16^{\circ} 19^{\prime} 58 \cdot 2^{\prime \prime} \mathrm{N} ; 107^{\circ} 25^{\prime} 17 \cdot 4^{\prime \prime} \mathrm{E}$. ZFMK 30594-30596, 3 ex., 104-2-127.5 mm $L_{\mathrm{S}}$; Vietnam: Quang Nam province, stream named Doi about $35 \mathrm{~km}$ west of Da Nang; $15^{\circ} 57^{\prime} 48 \cdot 6^{\prime \prime} \mathrm{N}$; $108^{\circ} 0^{\prime} 37 \cdot 2^{\prime \prime}$ E. ZFMK 30899, 1 ex., $81 \cdot 7 \mathrm{~mm} L_{\mathrm{S}}$; Vietnam: Quang Nam province, stream about $25 \mathrm{~km}$ west of Tam Ky and about $50 \mathrm{~km}$ south of Hoi An; $15^{\circ} 27^{\prime} 18^{\prime \prime} \mathrm{N} ; 108^{\circ} 17^{\prime} 45^{\prime \prime}$ E. ZFMK 31894, 1 ex., $57 \cdot 4 \mathrm{~mm} L_{\mathrm{S}}$; Vietnam: Quang Ngai Province, Song Ve about $40 \mathrm{~km}$ west of national highway 1; $14^{\circ} 43^{\prime} 10 \cdot 2^{\prime \prime} \mathrm{N}$; $108^{\circ} 35^{\prime} 34 \cdot 2^{\prime \prime}$ E. ZFMK 32062, 1 ex., $75 \cdot 2 \mathrm{~mm} L_{\mathrm{S}}$; Vietnam: Quang Ngai province, Song Tra Bong, about $35 \mathrm{~km}$ west of national highway 1; $15^{\circ} 15^{\prime} 39 \cdot 6^{\prime \prime} \mathrm{N}$; $108^{\circ} 29^{\prime} 51^{\prime \prime} \mathrm{E}$. ZFMK $32370-32374,5$ ex., $35 \cdot 8-50 \cdot 7 \mathrm{~mm} L_{\mathrm{S}}$; Vietnam: Quang Nam province, stream named Khe Bo $30 \mathrm{~km}$ west of national highway 1; $15^{\circ} 50^{\prime} 28 \cdot 2^{\prime \prime} \mathrm{N} ; 107^{\circ} 57^{\prime} 57 \cdot 6^{\prime \prime} \mathrm{E}$. ZFMK 32379-32383, 5 ex., 51.8$95.6 \mathrm{~mm} L_{\mathrm{S}}$; Vietnam: Binh Dinh province, Song An Lao $40 \mathrm{~km}$ north-west of national highway $1 ; 14^{\circ} 38^{\prime} 42 \cdot 6^{\prime \prime} \mathrm{N} ; 108^{\circ} 51^{\prime} 15 \cdot 6^{\prime \prime}$. ZFMK 32387, 1 ex., $92 \cdot 8 \mathrm{~mm}$ $L_{\mathrm{S}}$; Vietnam: Quang Binh province, Stream named Lôô; $17^{\circ} 27^{\prime} 17 \cdot 4^{\prime \prime} \mathrm{N}$; $106^{\circ} 33^{\prime} 44 \cdot 4^{\prime \prime}$. ZFMK 32388-32389, 2 ex., 83·3-101·7 mm $L_{\mathrm{S}}$; Vietnam: Quang Binh province, stream at Lê Ninh; $17^{\circ} 13^{\prime} 9 \cdot 6^{\prime \prime} \mathrm{N} ; 106^{\circ} 39^{\prime} 4 \cdot 8^{\prime \prime} \mathrm{E}$. ZFMK $32390-$ 32391, 2 ex., 83.3-107.7 $\mathrm{mm} L_{\mathrm{S}}$; Vietnam: Quang Binh province, stream named Khe Gio at Quang Tien; $17^{\circ} 51^{\prime} 2 \cdot 4^{\prime \prime} \mathrm{N} ; 106^{\circ} 23^{\prime} 6 \cdot 6^{\prime \prime}$ E. ZFMK 32392-32395, 4 ex., $50 \cdot 0-77 \cdot 4 \mathrm{~mm} L_{\mathrm{S}}$; Vietnam: Ha Tinh province, stream named Khe Luy at Ky 
Phuong; $18^{\circ} 00^{\prime} 3 \cdot 6^{\prime \prime} \mathrm{N} ; 106^{\circ} 27^{\prime} 25 \cdot 2^{\prime \prime} \mathrm{E}$. ZFMK 32385-32386, 2 ex., 63·3-64.6 mm $L_{\mathrm{S}}$; Vietnam: Quang Binh province, stream $1 \mathrm{~km}$ north of Xuan Trach; $17^{\circ} 38^{\prime} 44 \cdot 4^{\prime \prime} \mathrm{N}$; $106^{\circ} 14^{\prime} 21 \cdot 6^{\prime \prime}$ E. ZRC 46318, 1 ex., $86 \cdot 6 \mathrm{~mm} L_{\mathrm{S}}$; Vietnam: Binh Dinh province, stream named Nuoc Choc about $60 \mathrm{~km}$ north-west of Qui Nhon, a tributary of Song Vinh Than, $14^{\circ} 12^{\prime} 37 \cdot 2^{\prime \prime} \mathrm{N}$; $108^{\circ} 45^{\prime} 42 \cdot 6^{\prime \prime} \mathrm{E}$. ZRC 46319, 1 ex., $89.0 \mathrm{~mm} L_{S}$; Vietnam: Thua Thien Hue province, Song Rao Nho at Hong Ha village about $50 \mathrm{~km}$ west of Hue, $16^{\circ} 17^{\prime} 21^{\prime \prime} \mathrm{N}$; $107^{\circ} 21^{\prime} 35 \cdot 4^{\prime \prime} \mathrm{E}$.

\section{Diagnosis}

A species of Pterocryptis with an unusually large genital papilla; males with a long conical papilla, while females with a flat, leaf-shaped papilla with a small projection at the tip, and a unique combination of the following characters: head width $11 \cdot 6-15.4 \% L_{\mathrm{S}}$, head depth $8 \cdot 2-9.9 \% L_{\mathrm{S}}$, pelvic-fin length $7 \cdot 5-9 \cdot 6 \% L_{\mathrm{S}}$, length of dorsal-fin base $0 \cdot 8-1 \cdot 9 \% L_{\mathrm{S}}$, depth of caudal peduncle $6 \cdot 2-7 \cdot 6 \% L_{\mathrm{S}}$, and principal caudal-fin rays $14-16$.

\section{Description}

Body laterally compressed. Head somewhat depressed. Dorsal profile straight, descending gently from dorsal-fin origin to snout tip. Anterior profile of snout rounded. Anterior pair of nostrils tubular and anteromedial to maxillary barbel base. Posterior pair of nostrils bordered by fleshy dorsal and ventral membranes and posteromedial to maxillary barbel base. Eyes small, subcutaneous; located in anterior half of head; visible dorsally, but not ventrally.

Mouth subterminal; gape horizontal or very slightly oblique. Well-developed rictal fold present, consisting of large and fleshy upper lobe joined at corner of mouth with lower lobe, which is subtended by a short submandibular groove.

Teeth villiform. Dentary teeth in slightly curved, elongate bands narrowing posteriorly, reaching from symphysis almost to mouth corners; premaxillary teeth in broader, slightly curved rectangular bands. Vomerine teeth in two separate elliptical patches.

Maxillary barbels slightly flattened for entire length, reaching to anterior third of anal fin. Single pair of mandibular barbels present; located slightly anterolateral to gular fold; barbels flattened for most of length, reaching just beyond anal-fin origin. Most juveniles under c. $75 \mathrm{~mm} L_{\mathrm{S}}$ with two pairs of mandibular barbels.

Gill membranes separate and overlapping, free from isthmus. Branchiostegal rays $10(2), 11(21)$ or 12 (11). Gill rakers short, anteriormost rakers on lower first arch small and widely spaced; $2+5$ (19), 2+6 (12), 2+7 (2), 3+6 (1).

Distal margin of pectoral fin broadly convex, with 10 (1), 11 (15), 11,i (5), 12 (11) or 12,i (2) rays. Proximal two-thirds of first pectoral-fin element co-ossified into a spine. Pectoral spine and articulated segments sexually dimorphic in mature individuals. Males with spine broad and somewhat flattened dorsoventrally, with 4-5 serrations on posterior edge, increasing in size distally; proximal articulated segments with 4-5 serrations on posterior edge. Female or juvenile with spine slender, without serrations. Distal margin of pelvic-fin convex, with i,6 (4), i,7 (27) or i,7,i (3) rays. Distal margin of dorsal fin pointed, with 4 (34) rays and first ray simple; segments of first ray not co-ossified to form spine. Distal margin of anal fin straight, with 57 (1), 60 (3), 62 (3), 63 (2), 64 (2), 
(a)

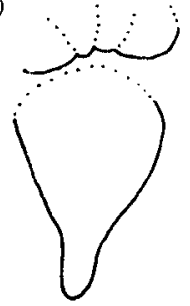

(c)

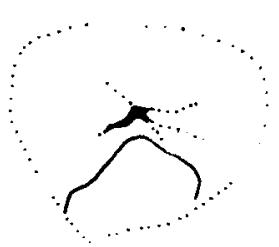

(e)

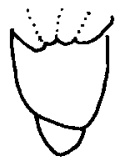

(b)

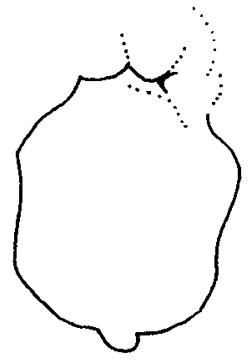

(d)

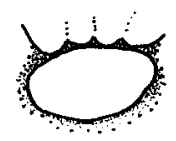

(f)

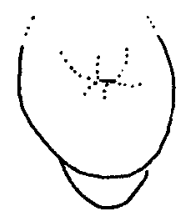

FIG. 2. Genital papilla of Pterocryptis species: (a) P. cochinchinensis, male, AMNH 227902, $144 \cdot 5 \mathrm{~mm} L_{\mathrm{S}}$; (b) P. cochinchinensis, female, AMNH $227874,146.9 \mathrm{~mm} L_{\mathrm{S}}$; (c) P. verecunda, male, CMK 14839, $131.6 \mathrm{~mm} L_{\mathrm{S}}$; (d) P. verecunda, female, CMK 14821, $97.5 \mathrm{~mm} L_{\mathrm{S}}$; (e) other Pterocryptis species, male ( $P$. inusitata, CMK 12534, $125.9 \mathrm{~mm} L_{\mathrm{S}}$ illustrated); (f) other Pterocryptis species, female ( $P$. inusitata, CMK 12534, $91.5 \mathrm{~mm} L_{\mathrm{S}}$ illustrated). Scale bar $1 \mathrm{~mm}$.

65 (5), 67 (1), 68 (6), 69 (1), 70 (2), 71 (1) or 73 (1) rays; joined to caudal fin for length of last anal-fin ray. Integument over anal fin thickened proximally for slightly more than half of ray lengths; fin-ray erector muscles extending along anterior edges of anal-fin rays, ventral-most extent of muscles that of thickened integument. Caudal fin emarginate; principal rays 7/7 (4), 7/8 (26), $8 / 7$ (1) or $8 / 8(6)$.

Urogenital papillae of both sexes located immediately posterior to anus. Males (5 specimens examined, $97 \cdot 8-200 \cdot 6 \mathrm{~mm} L_{\mathrm{S}}$ ) with a long conical papilla [Fig. 2(a)]; females (12 specimens examined, $96 \cdot 7-146.9 \mathrm{~mm} L_{\mathrm{S}}$ ) with a flat, leaf-shaped papilla bearing a small projection at tip [Fig. 2(b)].

Morphometric data as in Table I. Vertebrae $14+39=53(1), 15+39=54$ (4), $14+41=55(7), 15+40=55(2), 13+43=56(1), 14+42=56(2), 15+41=56(4)$, $14+43=57(2), 15+42=57(7)$ or $16+42=58(1)$.

\section{Colouration}

Flanks and thickened integument over anal fin pale brown with very distinct randomly distributed irregular dark patches. Dorsal surface and sides of head brown, without darker patches. Melanophores less dense ventral to level of eye; ventral surfaces of head, breast and belly yellow with scattered melanophores. Maxillary and mandibular barbels brown, gradually fading to yellow distally. 
TABLE I. Morphometric data for Vietnamese Pterocryptis

\section{P. cochinchinensis P. crenula P. cucphuongnesis $\quad$ P. verecunda}

\begin{tabular}{|c|c|c|c|c|}
\hline \multicolumn{5}{|l|}{ As $\% L_{\mathrm{S}}$} \\
\hline Head length & $17 \cdot 3-21 \cdot 1$ & $19 \cdot 2-19 \cdot 6$ & $19 \cdot 4-20 \cdot 8$ & $20 \cdot 3-21 \cdot 3$ \\
\hline Head width & $11 \cdot 6-15 \cdot 4$ & $13 \cdot 8-14 \cdot 7$ & $13 \cdot 9-16 \cdot 4$ & $15 \cdot 3-16 \cdot 2$ \\
\hline Head depth & $8 \cdot 2-9 \cdot 9$ & $10 \cdot 0-10 \cdot 1$ & $11 \cdot 2-12 \cdot 2$ & $10 \cdot 6-11 \cdot 7$ \\
\hline Predorsal distance & $27 \cdot 4-32 \cdot 2$ & $30 \cdot 3-30 \cdot 4$ & $27 \cdot 8-34 \cdot 3$ & $29 \cdot 6-31 \cdot 2$ \\
\hline Preanal length & $36 \cdot 0-39 \cdot 6$ & $36 \cdot 7-38 \cdot 5$ & $40 \cdot 8-41 \cdot 9$ & $38 \cdot 0-38 \cdot 9$ \\
\hline Prepelvic length & $29 \cdot 1-34 \cdot 8$ & $33 \cdot 1-33 \cdot 8$ & $34 \cdot 2-36 \cdot 9$ & $33 \cdot 6-34 \cdot 8$ \\
\hline Prepectoral length & $16 \cdot 4-20 \cdot 6$ & $17 \cdot 6-17 \cdot 9$ & $18 \cdot 6-19 \cdot 4$ & $17 \cdot 1-19 \cdot 3$ \\
\hline Body depth at anus & $13 \cdot 6-19 \cdot 4$ & $14 \cdot 5-15 \cdot 3$ & $12 \cdot 9-17 \cdot 3$ & $16 \cdot 3-17 \cdot 6$ \\
\hline Depth of caudal peduncle & $6 \cdot 2-7 \cdot 6$ & $6 \cdot 9-8 \cdot 4$ & $5 \cdot 3-7 \cdot 0$ & $6 \cdot 2-7 \cdot 2$ \\
\hline Pectoral-spine length & $4 \cdot 3-8 \cdot 9$ & $4 \cdot 9-6 \cdot 0$ & $11 \cdot 2$ & $3 \cdot 5-5 \cdot 6$ \\
\hline Pectoral-fin length & $9 \cdot 6-15 \cdot 7$ & $11 \cdot 6-13 \cdot 0$ & $13 \cdot 2-13 \cdot 9$ & $10 \cdot 6-12 \cdot 2$ \\
\hline Length of dorsal-fin base & $0 \cdot 8-1 \cdot 9$ & $1 \cdot 5-1 \cdot 6$ & $1 \cdot 6-2 \cdot 4$ & $1 \cdot 4-1 \cdot 6$ \\
\hline Pelvic-fin length & $7 \cdot 5-9 \cdot 6$ & $6 \cdot 6-7 \cdot 3$ & $6 \cdot 6-8 \cdot 4$ & $6 \cdot 6-7 \cdot 2$ \\
\hline Length of anal-fin base & $61 \cdot 0-67 \cdot 0$ & $62 \cdot 9-65 \cdot 5$ & $57 \cdot 4-59 \cdot 6$ & $61 \cdot 3-63 \cdot 1$ \\
\hline Caudal-fin length & $14 \cdot 6-17 \cdot 5$ & $15 \cdot 1-16 \cdot 5$ & $14 \cdot 7-17 \cdot 5$ & $13 \cdot 4-15 \cdot 5$ \\
\hline \multicolumn{5}{|l|}{ As $\% L_{\mathrm{H}}$} \\
\hline Snout length & $35 \cdot 2-41 \cdot 7$ & $34 \cdot 4-41 \cdot 3$ & $37 \cdot 0-38 \cdot 3$ & $36 \cdot 3-39 \cdot 2$ \\
\hline Interorbital distance & $47 \cdot 0-55 \cdot 6$ & $51 \cdot 7-52 \cdot 9$ & $48 \cdot 0-55 \cdot 9$ & $49 \cdot 7-52 \cdot 7$ \\
\hline Eye diameter & $7 \cdot 9-12 \cdot 8$ & $10 \cdot 0-12 \cdot 7$ & $8 \cdot 1-8 \cdot 5$ & $10 \cdot 0-12 \cdot 2$ \\
\hline Maxillary barbel length & $180 \cdot 0-257 \cdot 0$ & $190 \cdot 0-193 \cdot 6$ & $179 \cdot 2-213 \cdot 3$ & $194 \cdot 5-209 \cdot 0$ \\
\hline Mandibular barbel length & $66 \cdot 9-102 \cdot 1$ & $66 \cdot 9-85 \cdot 0$ & $\begin{array}{l}42 \cdot 8-68 \cdot 6 \text { (inner) } \\
59 \cdot 0-89 \cdot 4 \text { (outer) }\end{array}$ & $75 \cdot 6-80 \cdot 1$ \\
\hline
\end{tabular}

Anal fin with hyaline ventral margin. Caudal, pectoral and pelvic fins hyaline, with small dark-brown spots occasionally present.

\section{Distribution}

Known only from the coastal drainages in central Vietnam immediately south of Vinh to An Lao (Fig. 3).

\section{Remarks}

The exact identity of $P$. cochinchinensis has not been well-established. The species has been reported from many localities in South-east Asia. Pterocryptis cochinchinensis was described from specimens collected from 'Cochinchine' (presently southern Vietnam) by Pierre-Médard Diard (Kottelat, 1990: 214). Diard collected four other species of freshwater fishes from the same locality, namely Poropuntius deauratus (Valenciennes in Cuvier \& Valenciennes, 1842), Schistura spiloptera (Valenciennes in Cuvier \& Valenciennes, 1846) and Sewellia lineolata (Valenciennes in Cuvier \& Valenciennes, 1846). The latter three species have very restricted distributions and are known to occur together only in a few coastal drainages south of Hue (unpubl. data). Hue was formerly the imperial capital of Vietnam and would therefore be a very easily accessible and a likely place for a foreigner to visit. Based on the circumstantial evidence given above, it is concluded that the types of $P$. cochinchinensis were almost certainly collected from drainages in the vicinity of Hue. 


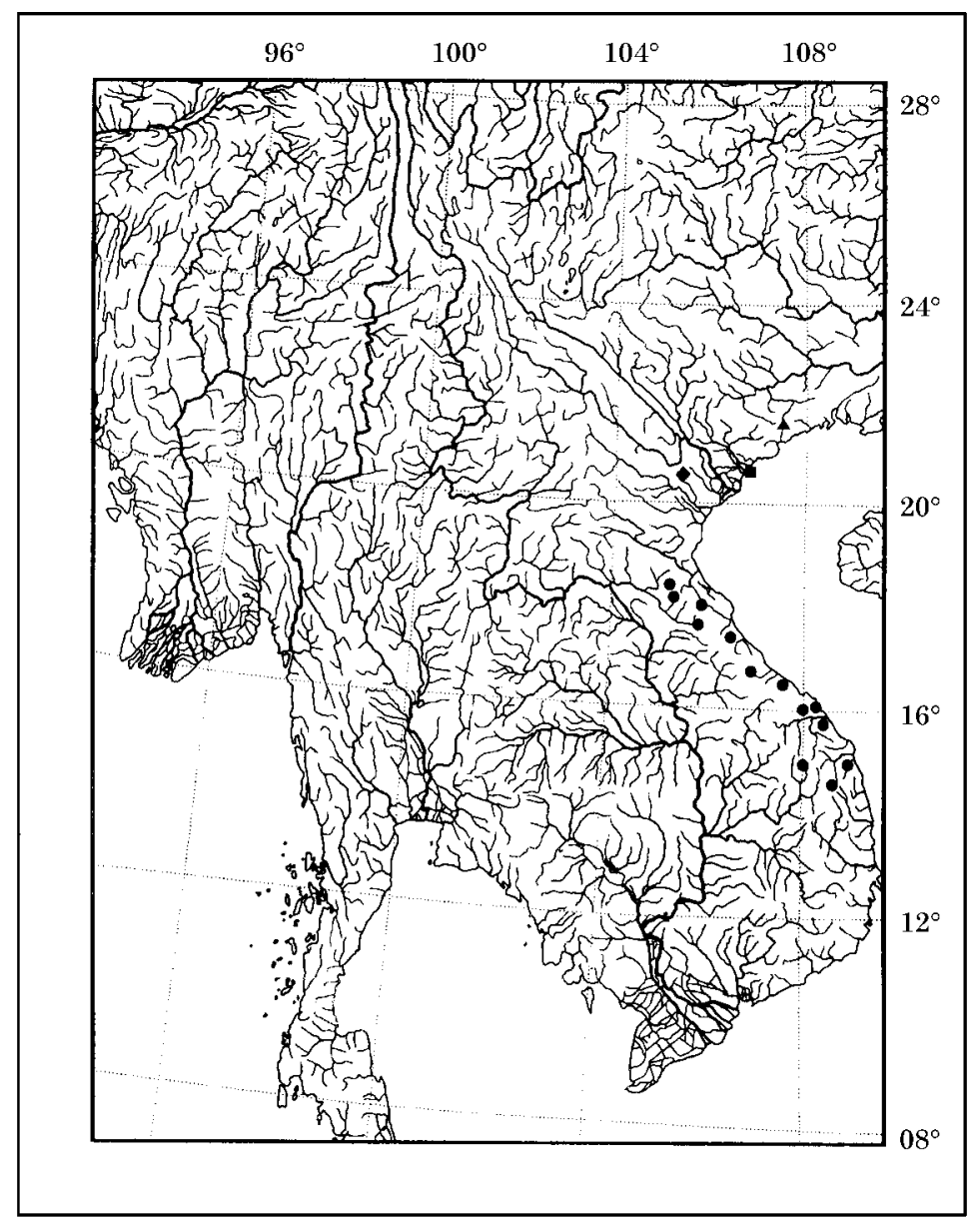

FIG. 3. Map showing distributions of Vietnamese Pterocryptis. Pterocryptis cochinchinensis $P$. crenula $(\mathbf{\Delta}), P$. cucphuongensis $(\bullet)$ and $P$. verecunda (

The present studies reveal that $P$. cochinchinensis has a more restricted distribution than previously thought. The species is found in the coastal drainages of central Vietnam (immediately south of Vinh to An Lao), and may not occur anywhere else (not enough material was available to determine the identity of the southern Chinese species).

Pterocryptis cochinchinensis differs from all congeners in having a larger genital papilla than in other congeners (Fig. 2): males have a long conical papilla [Fig. 2(a)] while females have a flat, leaf-shaped papilla with a small projection at the tip [Fig. 2(b)]. It further differs from both $P$. crenula and $P$. verecunda in having a bigger pelvic fin $\left(7 \cdot 5-9 \cdot 6 \% L_{\mathrm{S}} v \cdot 6 \cdot 6-7 \cdot 3\right.$; Fig. 4$)$, and from $P$. verecunda in having a more slender head (head depth 8.2-9.9 $\% L_{\mathrm{S}} v \cdot 10 \cdot 6-11 \cdot 7$; Fig. 5).

PTEROCRYPTIS CRENULA SP. NOV. (Fig. 6)

Pterocryptis cochinchinensis (non Valenciennes)—Ng, 1999a: 374 (in part). 


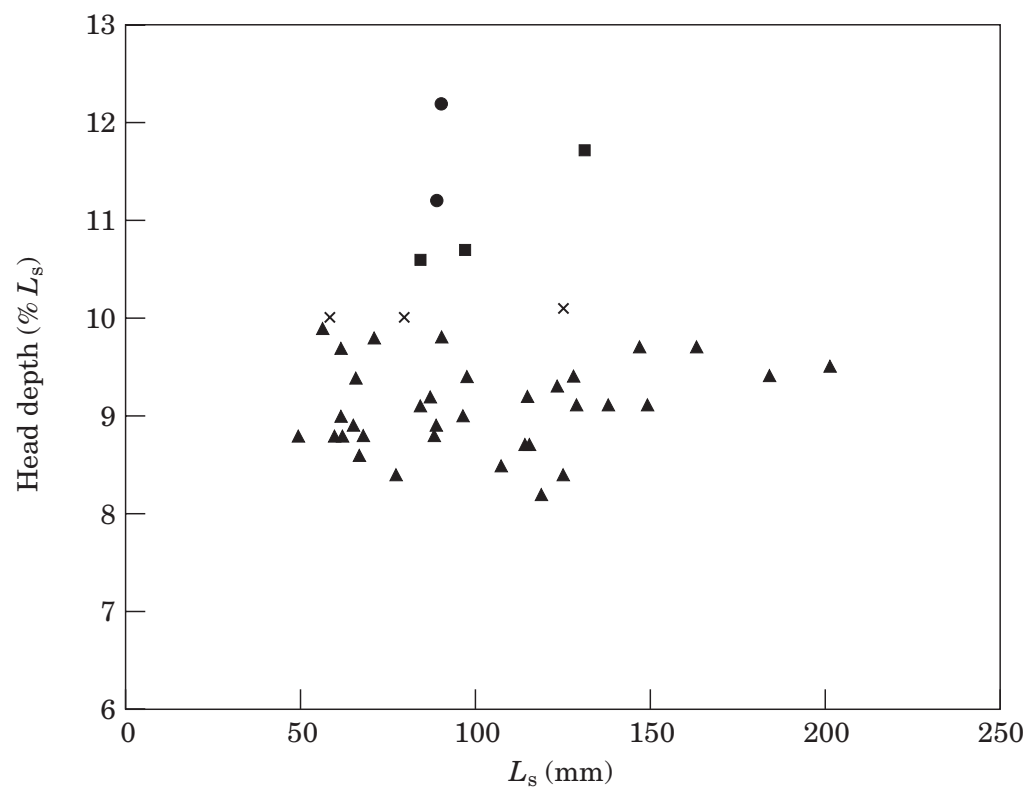

FIG. 5. Scatterplot of head depth $\left(\% L_{\mathrm{S}}\right)$ against $L_{\mathrm{S}}$ for $\boldsymbol{\Delta}, P$. cochinchinensis; $\times$, P. crenula; -, P. cucphuongensis; $\mathbf{\square}, P$. verecunda.

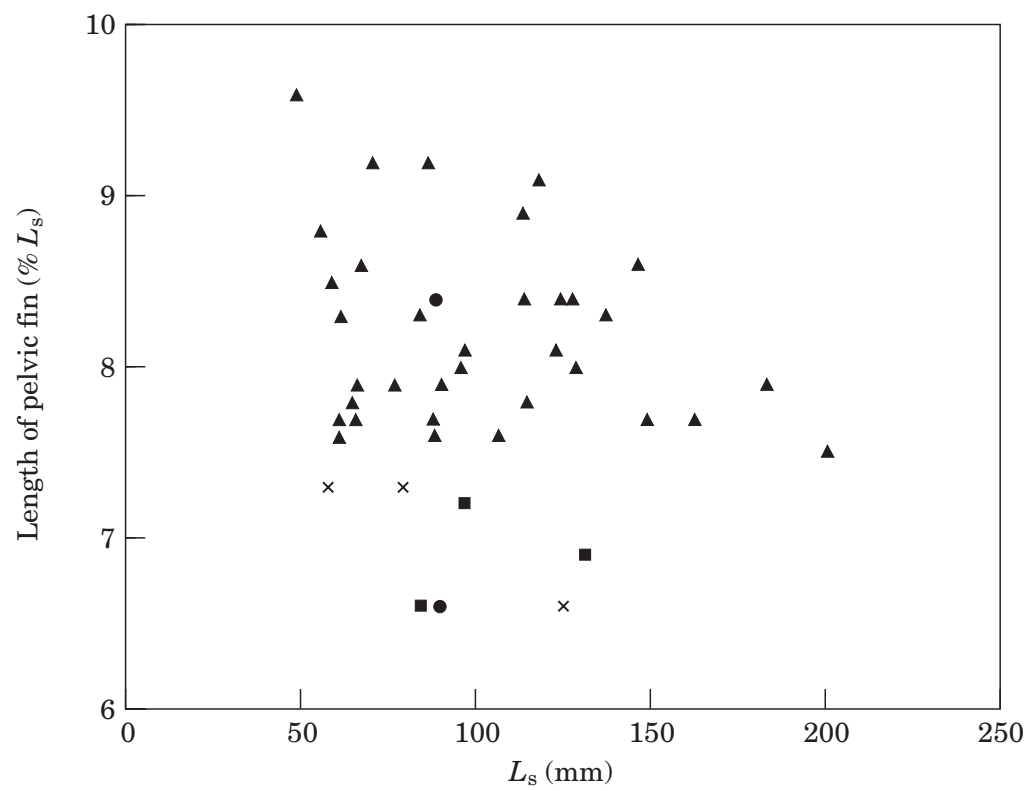

FIG. 4. Scatterplot of pelvic-fin length $\left(\% L_{\mathrm{S}}\right)$ against $L_{\mathrm{S}}$ for $\boldsymbol{\Delta}, P$. cochinchinensis; $\times$, P. crenula; -, P. cucphuongensis; $\mathbf{\square}, P$. verecunda.

\section{Holotype}

ZRC 46317, 125.2 $\mathrm{mm} L_{\mathrm{S}}$; Vietnam: Quang Ninh province, Hai Ninh district, torrent at $\mathrm{km} 5$ on road from Bac Phong Sinh to Mong Cai, 21 $35^{\prime} 31^{\prime \prime} \mathrm{N}$; $107^{\circ} 43^{\prime} 52^{\prime \prime} \mathrm{E}$; M. Kottelat, 2 October 1998. 


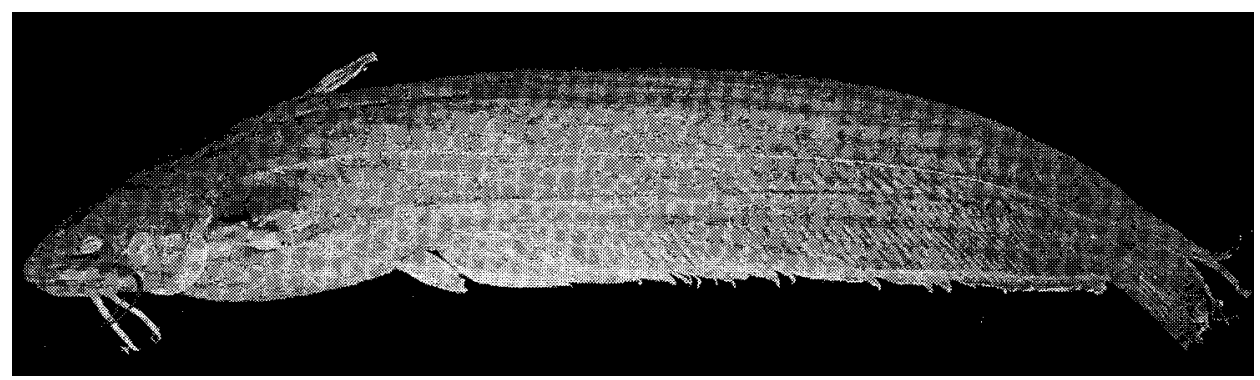

FIG. 6. Pterocryptis crenula, holotype, $125 \cdot 2 \mathrm{~mm} L_{\mathrm{S}}$; Vietnam: Quang Ninh province.

\section{Paratypes}

CMK 14895, 2 ex., 59.0-80.0 $\mathrm{mm} L_{\mathrm{S}}$; data as for holotype.

\section{Diagnosis}

A species of Pterocryptis with confluent anal and caudal fins separated only by a shallow ( $v$. deep) notch, and a unique combination of the following characters: head width $13 \cdot 8-14 \cdot 7 \% L_{\mathrm{S}}$, head depth $10 \cdot 0-10 \cdot 1 \% L_{\mathrm{S}}$, and pelvic-fin length $6 \cdot 6-7 \cdot 3 \% L_{S}$.

\section{Description}

Body laterally compressed. Head somewhat depressed. Dorsal profile straight, descending gently from dorsal-fin origin to snout tip. Anterior profile of snout rounded. Anterior pair of nostrils tubular and anteromedial to maxillary barbel base. Posterior pair of nostrils bordered by fleshy dorsal and ventral membranes and posteromedial to maxillary barbel base. Eyes small, subcutaneous; located in anterior half of head; visible dorsally, but not ventrally.

Mouth subterminal; gape horizontal or very slightly oblique. Well-developed rictal fold present, consisting of large and fleshy upper lobe joined at corner of mouth with lower lobe, which is subtended by a short submandibular groove.

Teeth villiform. Dentary teeth in slightly curved, elongate bands narrowing posteriorly, reaching from symphysis almost to mouth corners; premaxillary teeth in broader, slightly curved rectangular bands. Vomerine teeth present, in two separate elliptical patches.

Maxillary barbels slightly flattened for entire length, reaching to anterior third of anal fin. Single pair of mandibular barbels present; located slightly anterolateral to gular fold; barbels flattened for most of length, reaching to middle of pectoral-fin base.

Gill membranes separate and overlapping, free from isthmus. Branchiostegal rays 12 (2). Gill rakers short, anteriormost rakers on lower first arch small and widely spaced; $2+4$ (2).

Distal margin of pectoral fin broadly convex, with 12 (2) rays. Proximal two-thirds of first pectoral-fin element co-ossified into a spine. Pectoral spine and articulated segments sexually dimorphic in mature individuals. Males with spine broad and somewhat flattened dorsoventrally, with three serrations on posterior edge, increasing in size distally; articulated segments without serrations. Female or juvenile with spine slender and without posterior serrations. Distal margin of pelvic-fin convex, with i,7 (2) rays. Distal margin of dorsal fin 
pointed, with 4 (2) rays and first ray simple; segments of first ray not co-ossified to form spine. Distal margin of anal fin straight, with 61 (1) or 62 (1) rays; joined to caudal fin for length of last anal-fin ray. Integument over anal fin thickened proximally for slightly more than half of ray lengths; fin-ray erector muscles extending along anterior edges of anal-fin rays, ventralmost extent of muscles that of thickened integument. Caudal fin emarginate; principal rays 7/7 (2).

Urogenital papillae of both sexes located immediately posterior to anus. Males with a small conical papilla [Fig. 2(e)]; females with a similarly-shaped, but smaller papilla [Fig. 2(f)].

Morphometric data as in Table I. Vertebrae $15+40=55(1), 15+41=56(1)$ or $16+42=58(1)$.

\section{Colouration}

Flanks and thickened integument over anal fin pale brown with very distinct randomly distributed irregular dark patches. Dorsal surface and sides of head brown, without darker patches. Melanophores less dense ventral to level of eye; ventral surfaces of head, breast and belly yellow with scattered melanophores. Maxillary and mandibular barbels brown, gradually fading to yellow distally. Anal fin with hyaline ventral margin. Caudal, pectoral and pelvic fins hyaline, with small dark-brown spots occasionally present.

\section{Etymology}

From the Latin crenula meaning small notch, in reference to the relatively shallow notch between the confluent anal and caudal fins diagnostic of this species. Used as a noun.

\section{Distribution}

Known only from northeastern Vietnam (Fig. 3).

\section{Remarks}

Pterocryptis crenula can be distinguished from its congeners in having confluent anal and caudal fins separated only by a shallow ( $v$. deep) notch. Although all Pterocryptis have confluent anal and caudal fins (Bornbusch, 1991), they appear to be superficially disjunct because of the deep notch between the two fins. This is less apparent in $P$. crenula, where the fins are separated by a shallower notch and their confluence is more readily visible (Fig. 7).

\section{PTEROCRYPTIS CUCPHUONGENSIS (MAI, 1978) (Fig. 8)}

Silurus cucphuongensis Mai, 1978: 245, fig. 113 (type locality: Cuc Phuong, Vietnam); Mai, 1985: 284.

Pterocryptis cucphuongensis-Ng \& Kottelat, 1998: 399; Ng, 1999a: 374.

\section{Material examined}

ZMUH 345, 1 ex., holotype, 89.3 mm $L_{\mathrm{S}}$; Vietnam: Thanh Hoa province, Cuc Phuong National Park. ZRC 39524, 1 ex., 90.4 mm $L_{S}$; Vietnam: Thanh Hoa province, Cuc Phuong National Park, stream c. $16 \mathrm{~km}$ from gate. 
(a)

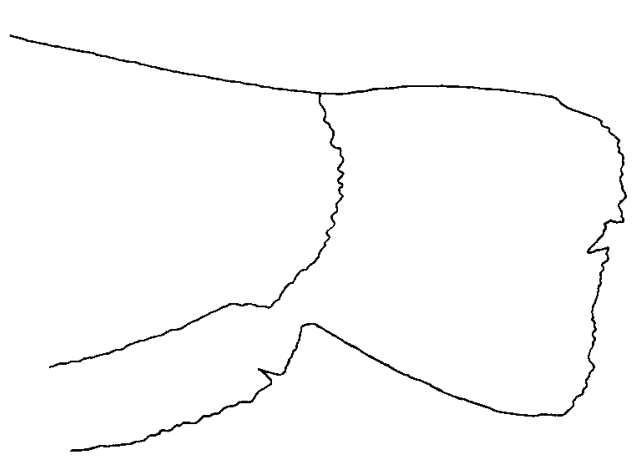

(b)

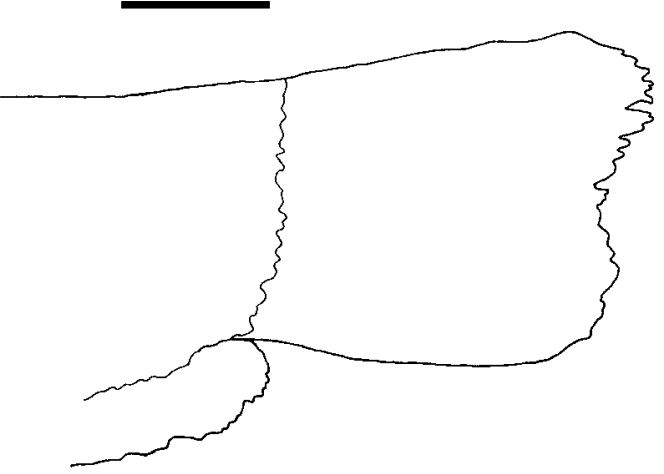

FIG. 7. Caudal and anal fins of: (a) P. crenula, ZRC 46317, holotype, $125 \cdot 2 \mathrm{~mm} L_{\mathrm{S}}$; (b) other Pterocryptis species (P. cochinchinensis, AMNH 231001, 96.7 $\mathrm{mm} L_{\mathrm{S}}$ illustrated). Scale bar $5 \mathrm{~mm}$.

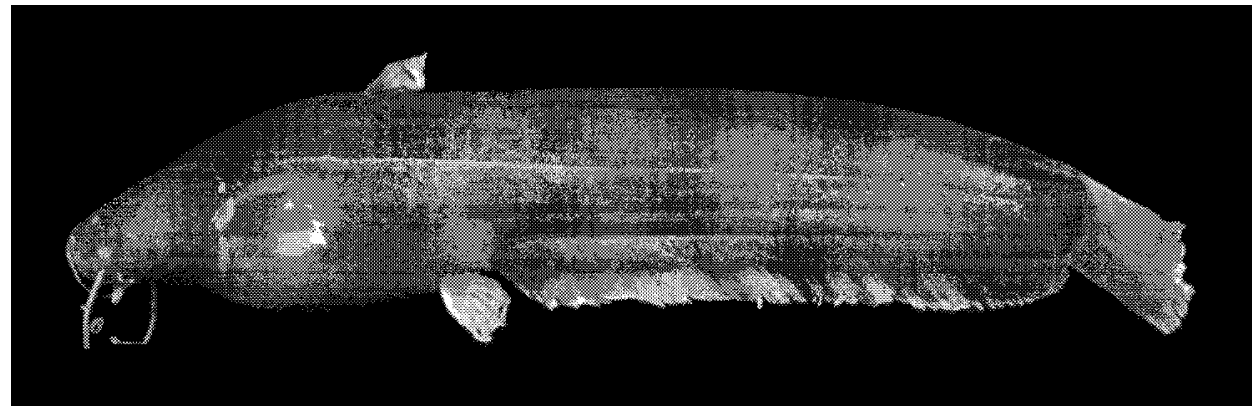

FIG. 8. Pterocryptis cucphuongensis, ZRC 39524, $90.4 \mathrm{~mm} L_{\mathrm{S}}$; Vietnam: Thanh Hoa province, Cuc Phuong National Park.

\section{Diagnosis}

A species of Pterocryptis with the following unique combination of characters: presence of four mandibular barbels; head length $19 \cdot 4-20 \cdot 8 \% L_{\mathrm{S}}$, head width $13 \cdot 9-16.4 \% L_{\mathrm{S}}$, vomerine teeth present in a single crescentic band, $51-54$ anal-fin rays, and gill rakers $2+5$ or $3+4$. 


\section{Description}

Body laterally compressed. Head somewhat depressed. Dorsal profile straight, descending gently from dorsal-fin origin to snout tip. Anterior profile of snout rounded. Anterior pair of nostrils tubular and anteromedial to maxillary barbel base. Posterior pair of nostrils bordered by fleshy dorsal and ventral membranes and posteromedial to maxillary barbel base. Eyes small, subcutaneous; located in anterior half of head; visible dorsally, but not ventrally.

Mouth subterminal; gape horizontal or very slightly oblique. Well-developed rictal fold present, consisting of large and fleshy upper lobe joined at corner of mouth with lower lobe, which is subtended by a short submandibular groove.

Teeth villiform. Dentary teeth in slightly curved, elongate bands narrowing posteriorly, reaching from symphysis almost to mouth corners; premaxillary teeth in broader, slightly curved rectangular bands. Vomerine teeth in a single crescentic band.

Maxillary barbels slightly flattened for entire length, reaching to anterior third of anal fin. Two pairs of mandibular barbels present; located slightly anterolateral to gular fold; barbels flattened for most of length, reaching to middle of pectoral-fin base.

Gill membranes separate and overlapping, free from isthmus. Branchiostegal rays 11 (1) or 12 (1). Gill rakers short, anteriormost rakers on lower first arch small and widely spaced; $2+5$ (1) or $3+4$ (1).

Distal margin of pectoral fin broadly convex, with 7 (1) or 10,i (1) rays. Proximal two-thirds of first pectoral-fin element co-ossified into a spine. Pectoral spine and articulated segments sexually dimorphic in mature individuals. Males with spine broad and somewhat flattened dorsoventrally, with five serrations on posterior edge, increasing in size distally; proximal articulated segments with three serrations on posterior edge. Female or juvenile with spine slender, without serrations. Distal margin of pelvic-fin convex, with i,6 (1) or i,7 (1) rays. Distal margin of dorsal fin pointed, with 4 (2) rays and first ray simple; segments of first ray not co-ossified to form spine. Distal margin of anal fin straight, with 51 (1) or 54 (1) rays; joined to caudal fin for length of last anal-fin ray. Integument over anal fin thickened proximally for slightly more than half of ray lengths; fin-ray erector muscles extending along anterior edges of anal-fin rays, ventral-most extent of muscles that of thickened integument. Caudal fin emarginate; principal rays 7/7 (1) or 7/8 (1). Urogenital papillae of both sexes located immediately posterior to anus. Males (1 specimen examined, $89 \cdot 3 \mathrm{~mm}$ $\left.L_{\mathrm{S}}\right)$ with a small conical papilla [Fig. 2(e)]; females (1 specimen examined, $90.4 \mathrm{~mm} L_{\mathrm{S}}$ ) with a similarly-shaped, but smaller papilla [Fig. 2(f)].

Morphometric data as in Table I. Vertebrae $16+37=53(1)$.

\section{Colouration}

Flanks and thickened integument over anal fin pale brown with very distinct randomly distributed irregular dark patches. Dorsal surface and sides of head brown, without darker patches. Melanophores less dense ventral to level of eye; ventral surfaces of head, breast and belly yellow with scattered melanophores. Maxillary and mandibular barbels brown, gradually fading to yellow distally. Anal fin with hyaline ventral margin. Caudal, pectoral and pelvic fins hyaline, with small dark-brown spots occasionally present. 


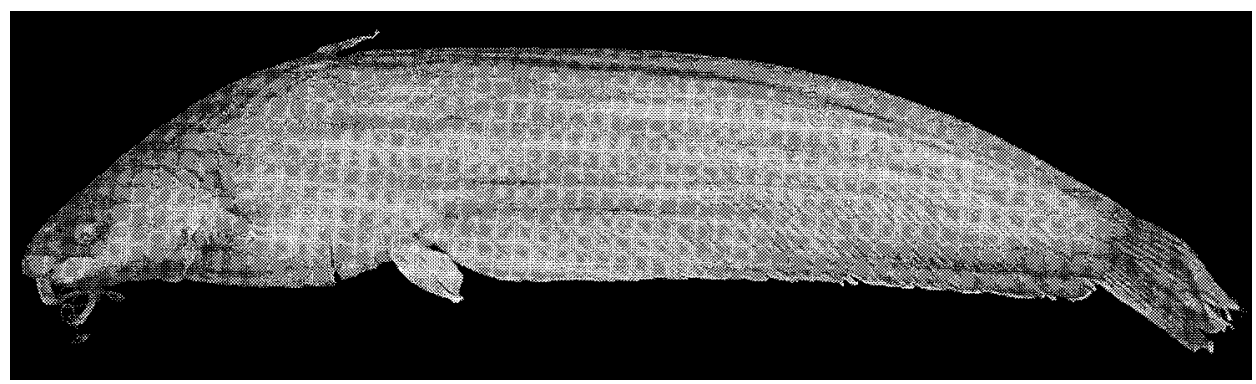

FIG. 9. Pterocryptis verecunda, CMK 14839, holotype, $131.6 \mathrm{~mm} L_{\mathrm{S}}$; Vietnam: Hai Phong province, Cat Ba Island.

\section{Distribution}

Known only from Song Iuong drainage in northern Vietnam (Fig. 3).

\section{Remarks}

Pterocryptis cucphuongensis differs from other Vietnamese species of Pterocryptis in having fewer anal-fin rays (51-54 v. 56-62), and in the adults having two ( $v$. one) pairs of mandibular barbels. It further differs from the other Vietnamese Pterocryptis in having the vomerine teeth in a single crescentic band (v. two distinct patches).

Since the original description of $P$. cucphuongensis is in Vietnamese and not readily understood by many, this species has been redescribed for the ease of future comparisons.

PTEROCRYPTIS VERECUNDA SP. NOV. (Fig. 9)

Pterocryptis cochinchinensis (non Valenciennes)—Ng, 1999a: 374 (in part).

\section{Holotype}

ZRC 46316, 1 ex., 131.6 mm $L_{\mathrm{S}}$; Vietnam: Hai Phong province, Cat Ba Island, stream near eastern entrance of Trung Trang cave $\left(20^{\circ} 47^{\prime} 17^{\prime \prime} \mathrm{N} ; 107^{\circ} 0^{\prime} 4^{\prime \prime} \mathrm{E}\right)$; M. Kottelat et al., 26 September 1998.

\section{Paratypes}

CMK 14821, 2 ex., 84.8-97.5 $\mathrm{mm} L_{\mathrm{S}}$; Vietnam: Hai Phong province, Cat $\mathrm{Ba}$ Island, first unnamed stream on road from National Park headquarters to Gia Luan (Ra Luan), c. $1 \mathrm{~km}\left(20^{\circ} 48^{\prime} 1^{\prime \prime} \mathrm{N} ; 106^{\circ} 59^{\prime} 3^{\prime \prime} \mathrm{E}\right)$; M. Kottelat et al., 25 September 1998.

\section{Diagnosis}

A species of Pterocryptis with the genital papilla partly concealed by the anus, and a unique combination of the following characters: head width $15 \cdot 3-16 \cdot 2$ $\% L_{\mathrm{S}}$, head depth $10 \cdot 6-11 \cdot 7 \% L_{\mathrm{S}}$, and pelvic-fin length 6.6-7.2 $\% L_{\mathrm{S}}$.

\section{Description}

Body laterally compressed. Head somewhat depressed. Dorsal profile straight, descending gently from dorsal-fin origin to snout tip. Anterior profile of snout rounded. Anterior pair of nostrils tubular and anteromedial to 
maxillary barbel base. Posterior pair of nostrils bordered by fleshy dorsal and ventral membranes and posteromedial to maxillary barbel base. Eyes small, subcutaneous; located in anterior half of head; visible dorsally, but not ventrally.

Mouth subterminal; gape horizontal or very slightly oblique. Well-developed rictal fold present, consisting of large and fleshy upper lobe joined at corner of mouth with lower lobe, which is subtended by a short submandibular groove.

Teeth villiform. Dentary teeth in slightly curved, elongate bands narrowing posteriorly, reaching from symphysis almost to mouth corners; premaxillary teeth in broader, slightly curved rectangular bands. Vomerine teeth in two separate elliptical patches.

Maxillary barbels slightly flattened for entire length, reaching to anterior third of anal fin. Single pair of mandibular barbels present; located slightly anterolateral to gular fold; barbels flattened for most of length, reaching to middle of pectoral-fin base.

Gill membranes separate and overlapping, free from isthmus. Branchiostegal rays 11 (1) or 12 (2). Gill rakers short, anteriormost rakers on lower first arch small and widely spaced; $2+4$ (1) or $2+5$ (1).

Distal margin of pectoral fin broadly convex, with 11 (2) or 12 (1) rays. Proximal two-thirds of first pectoral-fin element co-ossified into a spine. Pectoral spine and articulated segments sexually dimorphic in mature individuals. Males with spine broad and somewhat flattened dorsoventrally, with three serrations on posterior edge, increasing in size distally; proximal articulated segments with three serrations on posterior edge. Female or juvenile with spine slender, without serrations. Distal margin of pelvic-fin convex, with i,7 (1) or i,8 (2) rays. Distal margin of dorsal fin pointed, with 4 (3) rays and first ray simple; segments of first ray not co-ossified to form spine. Distal margin of anal fin straight, with 56 (1), 57 (1) or 61 (1) rays; joined to caudal fin for length of last anal-fin ray. Integument over anal fin thickened proximally for slightly more than half of ray lengths; fin-ray erector muscles extending along anterior edges of anal-fin rays, ventralmost extent of muscles that of thickened integument. Caudal fin emarginate; principal rays $7 / 7$ (1) or 7/8 (2).

Urogenital papillae of both sexes located immediately posterior to and partly concealed by anus. Males (1 specimen examined, $\left.131.6 \mathrm{~mm} L_{\mathrm{S}}\right)$ with a papilla resembling a small flap [Fig. 2(c)]; females (2 specimens examined, $84.8-97 \cdot 5 \mathrm{~mm}$ $L_{\mathrm{S}}$ ) with a papilla in the form of a round protuberance [Fig. 2(d)].

Morphometric data as in Table I. Vertebrae $15+40=55(1)$.

\section{Colouration}

Flanks and thickened integument over anal fin pale brown with very distinct randomly distributed irregular dark patches. Dorsal surface and sides of head brown, without darker patches. Melanophores less dense ventral to level of eye; ventral surfaces of head, breast and belly yellow with scattered melanophores. Maxillary and mandibular barbels brown, gradually fading to yellow distally. Anal fin with hyaline ventral margin. Caudal, pectoral and pelvic fins hyaline, with small dark-brown spots occasionally present. 


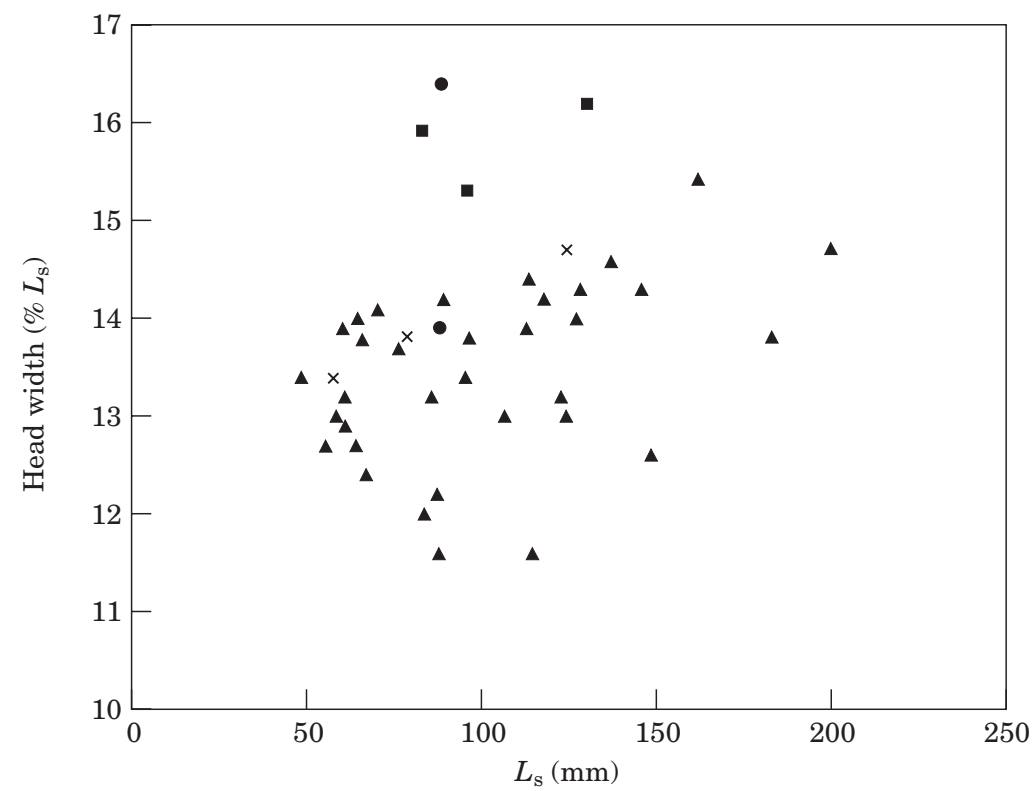

FIG. 10. Scatterplot of head width $\left(\% L_{\mathrm{S}}\right)$ against $L_{\mathrm{S}}(\mathrm{mm})$ for $\boldsymbol{\Delta}, P$. cochinchinensis; $\times$, P. crenula; - P. cucphuongensis; $\mathbf{\square}$, P. verecunda.

\section{Etymology}

From the Latin verecundus meaning shy, in reference to the genital papilla of this species, which is partly concealed by the anus. The name is used as an adjective.

\section{Distribution}

Known only from Cat Ba Island in northeastern Vietnam.

\section{Remarks}

Pterocryptis verecunda differs from all other congeners in having the genital papilla partly concealed by the anus ( $v$. highly visible genital papilla not concealed by anus; Fig. 2). It further differs from $P$. cochinchinensis and $P$. crenula in having a wider $\left(15 \cdot 3-16 \cdot 2 \% L_{\mathrm{S}}\right.$ v. 11.6-15.4; Fig. 10) and deeper $\left(10 \cdot 6-11 \cdot 7 \% L_{\mathrm{S}}\right.$ v. 8.2-9.9; Fig. 5) head.

\section{DISCUSSION}

There is a very small amount of intraspecific variation for Pterocryptis in the number of mandibular barbels: some species possess either one or two pairs of mandibular barbels, depending on age (and size). This ontogenetic variation has been observed in Pterocryptis: juvenile specimens $\left(<55-65 \mathrm{~mm} L_{\mathrm{S}}\right)$ possess two pairs of mandibular barbels, but one pair will gradually regress until it disappears with increasing age (Bornbusch, 1995). Observations of the authors support this, as six out of nine specimens of $P$. cochinchinensis $<c .75 \mathrm{~mm} L_{\mathrm{S}}$ examined have two pairs of mandibular barbels, while all specimens $>75 \mathrm{~mm} L_{\mathrm{S}}$ 
have only one pair. This phenomenon has also been reported for other silurid genera, most notably in Ompok by Parameswaran et al. (1971), Silurus by Atoda (1935) and Xie (1989), and Wallago by Majumdar (1951).

Even when both forms are seen in specimens of the same species and size, such cases of variation are rare (Chen, 1977; Bornbusch, 1991) and the number of mandibular barbels seems to be a character that can be used with some degree of confidence to diagnose species of Pterocryptis.

Another two diagnostic characters that have been found to be useful in distinguishing the Vietnamese species of Pterocryptis are the shapes of the genital papillae and the degree of fusion of the anal and caudal fins. The shapes of the genital papillae have not been previously used as diagnostic characters in silurids, although they have been used successfully in other siluriform groups such as akysids (Ng \& Ng, 2001), auchenipterids (Soares-Porto, 1998), clariids (Ng, $1999 \mathrm{~b}$ ) and sisorids ( $\mathrm{Ng} \&$ Kottelat, 1999). Given the importance of the reproductive structures in maintaining the historical individuality of lineages in the light of their role in breeding, it is surprising that they have not been used more frequently in diagnosing species.

The fusion of the anal and caudal fins is a synapomorphy of Pterocryptis and its sister taxon, Silurichthys. However, the degree of fusion of the anal and caudal fins in Silurichthys is considered more apomorphic in that the fins are united, but not separated by a distinct notch (Bornbusch, 1991). In this regard, the degree of fin fusion seen in P. crenula approaches that of Silurichthys in having a reduced notch between the fins. However, the lack of information from internal skeletal characters (which have not been examined) does not allow more to be said about the relationship between $P$. crenula and Silurichthys. The degree of fin fusion has been reliably used to diagnose species of clariids (Lim \& $\mathrm{Ng}$, 1999), and given the fact that there is no variation in the degree of fin fusion observed in the specimens examined, can be reliably used to diagnose species of Pterocryptis.

The difficulty of using morphometric measurements in diagnosing species of Pterocryptis is a problem that is also encountered among certain siluriform groups (e.g. the akysid catfish Acrochordonichthys, $\mathrm{Ng} \& \mathrm{Ng}, 2001$ ), the only solution to which would be to examine large series of specimens. This was not possible so except for the case of $P$. cochinchinensis, where the observed variation in head width, head depth and pelvic-fin length (Figs 4, 5 \& 10) still enabled the use of these characters with some confidence as a diagnostic.

Since Pterocryptis is found in the Indian subcontinent, mainland Southeast Asia and Borneo as well, the other nominal species are compared broadly with all of the Vietnamese ones here and subsequent comparisons will be limited among the Vietnamese species only.

Pterocryptis afghana (Günther, 1864) (reportedly from Afghanistan, but in fact probably from Assam; Hora, 1936: 354) can be distinguished from the Vietnamese species in having ( $v$. absence of) tubercles on the head and body and more vertebrae (60 v. 50-57). Pterocryptis gangelica Peters, 1861 (originally described from the Ganges, India) differs from the Vietnamese species in having fewer branchiostegal $(9 v .10-12)$ and (except for $P$. cochinchinensis) more anal-fin rays (67-75 v. 51-62). Pterocryptis indicus (Datta, Barman \& Jayaram, 1987) (from the Brahmaputra basin, India) can be distinguished from the 
Vietnamese species in having more anal-fin rays (85 v. 51-62), a rounded ( $v$. truncate) caudal fin, and fewer dorsal-fin rays (1 v. 2-5). Pterocryptis wynaadensis (Day, 1873) (from Tamil Nadu, India) can be distinguished from the Vietnamese species in having a smaller eye (eye diameter $7 \cdot 4 \%$ LH v. 7.9-12.7) and a rounded ( $v$. truncate) caudal fin. Both $P$. indicus and $P$. wynaadensis further differs from $P$. cochinchinensis, $P$. crenula and $P$. verecunda in having two (v. one) pairs of mandibular barbels.

Pterocryptis gilberti can be distinguished from all Vietnamese species except for $P$. cucphuongensis in having two ( $v$. one) pairs of mandibular barbels. It can be distinguished from $P$. cucphuongensis in having more anal-fin rays (57-66 v. 51-54) and pelvic-fin rays (8-10 v. 7-8). As pointed out by Bornbusch (1991), Kobayakawa (1989) did not mention or discuss the validity of $P$. anomala (Herre, 1933). Because of the lack of sufficient material from southern China available, it was not possible to determine if $P$. anomala was a valid species distinct from $P$. cochinchinensis. Therefore, the present authors tentatively concur with Haig (1952) and Chen (1977) and conclude that the two nominal species are conspecific.

In the brief original description of Silurichthys berdmorei, Blyth (1860: 156) mentioned that the species upper jaw was 'slightly longer than the lower' and the anal fin was 'continuous with the caudal, but distinctly defined'. Bornbusch's (1991) proposal that S. berdmorei be assigned to Pterocryptis instead was partly based on these characters.

Pterocryptis berdmorei was described from the Tenasserim region in southern Myanmar (Burma). The original description is very brief, but the species was described as having 3-4 dorsal fin rays, 65 anal-fin rays, and having one pair of mandibular barbels. Kobayakawa (1989) subsequently described P. torrentis (as Silurus torrentis) from southern Thailand and Myanmar. Three specimens from the Tenasserim region (NRM 28552) were among those she examined; these were subsequently designated as paratypes of $P$. torrentis. As mentioned in Bornbusch (1991), Kobayakawa failed to discuss the validity of $P$. berdmorei, even though both $P$. torrentis and $P$. berdmorei occur sympatrically in the Tenasserim. Of the characters used to distinguish $P$. torrentis from its congeners, no significant difference is apparent between $P$. torrentis and $P$. berdmorei in the number of anal-fin rays [63-74 in $P$. torrentis $v$. 65 in $P$. berdmorei as given by Blyth (1860) in the original description and 62-64 as given by Day (1877) subsequently] and the number of mandibular barbels (one pair given in all three descriptions). Comparisons of the descriptions of $P$. berdmorei with the original description and specimens of $P$. torrentis indicate that these features are insufficient to distinguish the two species.

The only noticeable difference between the descriptions of $P$. torrentis and that of $P$. berdmore $i$ is the shape of the vomerine tooth patch (given as a continuous band in $P$. torrentis and as two separate oval patches in $P$. berdmorei). However, examination of specimens of $P$. torrentis reveal that in some specimens (ZRC 2989, 92.5 $\mathrm{mm} L_{\mathrm{S}}$ ), the central space in the vomerine tooth plate is devoid of teeth, making it appear as two discrete, albeit very closely situated, patches.

The most appropriate thing to do in the light of all these problems is to compare the holotypes of the two nominal species. The holotype of P. berdmorei 
is deposited in the Indian Museum (=Zoological Survey of India), Calcutta, India (ZSI) according to Day (1877). However, some of the type material in the ZSI was lost during the Second World War as the result of a flood (Whitehead \& Talwar, 1976). Until an exhaustive search is conducted within the ZSI for the holotype, it would be unwise to assume that the holotype of $P$. berdmorei is really lost, although the fact that this species was not mentioned in the type catalogue of Menon \& Yazdani (1968) lends evidence to this supposition. Therefore, bearing in mind in the lack of significant differences between the descriptions of $P$. berdmorei and specimens of $P$. torrentis examined and the fact that both species are described from the same area (Tenasserim), there does not seem to be any valid reason to consider both species as distinct. Pterocryptis torrentis is hereby considered a junior subjective synonym of $P$. berdmorei here.

Arun Kumar \& Tombi Singh (1997) described Silurus morehensis from the headwaters of the Yu River (part of the Irrawaddy River drainage). From the original description, $S$. morehensis is clearly referable to Pterocryptis. The characters used to distinguish $P$. morehensis from $P$. berdmorei (the original description compares the species with $P$. torrentis) are not particularly useful: $P$. morehensis was distinguished from $P$. berdmorei on the basis of having a more slender caudal peduncle, longer maxillary barbels and shorter mandibular barbels. The depth of the caudal peduncle does not differ significantly between $P$. morehensis $\left(5 \cdot 1-6 \cdot 8 \% L_{\mathrm{S}}\right)$ and $P$. berdmorei $\left(5 \cdot 3-6 \cdot 7 \% L_{\mathrm{S}}\right)$, and the lengths of barbels in catfishes are highly dependent on a variety of external factors, which may include water conditions and whether or not the tips have been bitten off. It is for these reasons that $P$. morehensis is considered a junior subjective synonym of $P$. berdmorei here.

Pterocryptis berdmorei differs from the Vietnamese species in having a larger dorsal-fin base $\left(2 \cdot 4-4 \cdot 2 \% L_{\mathrm{S}} v \cdot 0 \cdot 8-2 \cdot 4\right)$ and in having more principal caudal rays (17-18 v. 14-16). It further differs from $P$. cochinchinensis in having a more slender caudal peduncle $\left(5 \cdot 3-6 \cdot 7 \% L_{\mathrm{S}} v \cdot 6 \cdot 2-7 \cdot 6\right)$, from $P$. cucphuongensis in having a larger eye $(9 \cdot 4-12 \cdot 6 \% \mathrm{LH} v .8 \cdot 1-8 \cdot 5)$, fewer gill rakers $(4 v .7)$ on the first gill arch, and from $P$. verecunda in having a narrower $\left(13 \cdot 1-14 \cdot 8 \% L_{\mathrm{S}} v\right.$. 15·3-16.2) head.

Pterocryptis bokorensis (Pellegrin \& Chevey, 1937) differs from the Vietnamese species of Pterocryptis in having a shorter head $\left(12 \cdot 4 \% L_{\mathrm{S}} v .17 \cdot 3-21 \cdot 3\right)$ and, except for $P$. cucphuongensis, in having two ( $v$. one) pairs of mandibular barbels.

Pterocryptis buccata $\mathrm{Ng} \&$ Kottelat, 1998 can be clearly distinguished from all its congeners by its prominent mandibular muscles causing the cheeks to appear inflated. It further differs from $P$. cochinchinensis, $P$. crenula and $P$. verecunda in the adults having two ( $v$. one) pairs of mandibular barbels, and from the latter two species in having a bigger pelvic fin $\left(7 \cdot 7-8 \cdot 8 \% L_{\mathrm{S}} v \cdot 6 \cdot 6-7 \cdot 3\right)$.

Pterocryptis burmanensis (Kin Thant, 1966) can be distinguished from all other congeners in Vietnam in having more anal-fin rays (73-75v. 51-73) and (except for P. cucphuongenesis) two ( $v s$ one) pairs of mandibular barbels.

Pterocryptis inusitata $\mathrm{Ng}, 1999$ can be distinguished from the Vietnamese species in having more gill rakers on the first gill arch (9-11 v. 6-7) and an elliptical ( $v$. circular) eye. It further differs from $P$. cucphuongensis in having a larger eye $(10 \cdot 3-13 \cdot 2 \% \mathrm{LH} v .8 \cdot 1-8 \cdot 5)$, and from $P$. verecunda in having a shorter head $\left(17 \cdot 2-19 \cdot 9 \% L_{\mathrm{S}}\right.$ v. 20.3-21·3). 
Pterocryptis furnessi (Fowler, 1905) can be distinguished from the Vietnamese species in having fewer anal-fin rays (42-55 v. 51-73), a highly mottled brown colouration ( $v$. dull pale brown colouration), and a longer head $\left(20 \cdot 4-22.4 \% L_{\mathrm{S}}\right.$ v. $17 \cdot 3-21 \cdot 3)$.

\section{COMPARATIVE MATERIAL}

Pterocryptis berdmorei: NRM 29548, 7 ex., paratypes of Silurus torrentis, 83·1-153.2 mm $L_{\mathrm{S}}$; Myanmar: Kachin State, Putao (Ft. Hertz). NRM 28552, 3 ex., paratypes of Silurus torrentis, 145.7-178 $\mathrm{mm} L_{\mathrm{S}}$; Myanmar: Tenasserim/ Mon State, south of Ye, Malvedaung. BMNH 1893.6.30.110, 1 ex., 125.0 mm $L_{\mathrm{S}}$; Myanmar: Shan States, Nampandet. BMNH 1972.7.26.11, 1 ex., 216.2 mm $L_{\mathrm{S}}$; upper Myanmar. ZRC 2989, 1 ex., $92.5 \mathrm{~mm} L_{\mathrm{S}}$; Kedah, Baling. ZRC 41970, 1 ex., 138.6 mm $L_{S}$; Thailand: Ranong province, King Amphoe Suk Sam Lan, Ton Koi waterfall. ZRC 42205, 1 ex., $68.3 \mathrm{~mm} L_{\mathrm{S}}$; Thailand: Ranong province, Khlong Kho Krue at Ban Cho Krue, km $3 \cdot 5$ on road to Nam Tok Kho Krue, branching $\mathrm{E} 3 \mathrm{~km} \mathrm{~S}$ of Kra Buri on road to Ranong.

P. bokorensis: MNHN 1936-167, 1 ex., holotype, 124.4 mm $L_{\mathrm{S}}$; Cambodia: Bokor, 800-1000 $\mathrm{m}$ altitude.

P. buccata: ZRC 41496, 1 ex., holotype, 95.6 mm $L_{\mathrm{S}}$; Thailand: Kanchanaburi Province, Amphoe Sai Yok, Mae Khlong basin. CMK 5993, 1 ex., paratype, $82.5 \mathrm{~mm} L_{\mathrm{S}}$; data as for holotype. CMK 12884, 1 ex., paratype, 146.6 $\mathrm{mm} L_{\mathrm{S}}$; Thailand: Kanchanaburi Province, Sai Yok Noi caves near Nam Tok.

P. gangelica: CAS 141890, 1 ex., 136.5 mm $L_{\mathrm{S}}$; ZSI F13421/1, 3 ex., 81.5$111 \cdot 1 \mathrm{~mm} L_{\mathrm{S}}$; India: West Bengal State, Tista river drainage, Kalimpong Duars and Siliguri Terai.

P. gilberti: USNM 293931, 1 ex., $91.9 \mathrm{~mm} L_{\mathrm{S}}$; China: Hainan Island: Changjing River. USNM 293933, 1 ex., $68.5 \mathrm{~mm} L_{\mathrm{S}}$; China: Guizhou province, Beipanjiang.

P. indicus: ZSI FF1699, 1 ex., holotype, $204.6 \mathrm{~mm} L_{\mathrm{S}}$; India: Arunachal Pradesh State, Namdapha River.

P. inusitata: ZRC 41455, 1 ex., holotype, $173.7 \mathrm{~mm} L_{\mathrm{S}}$; Laos: Mekong basin, Nam Theun watershed, Nam Ong at Ban Don. CMK 12534, 3 ex., paratypes, 91.5-183.9 $\mathrm{mm} L_{\mathrm{S}}$; Laos: Khammouan Province, Nam Theun, from Ban Signo to about $6 \mathrm{~km}$ upriver; $17^{\circ} 50^{\prime} 50^{\prime \prime} \mathrm{N} 105^{\circ} 03^{\prime} 00^{\prime \prime} \mathrm{N}$. CMK 12570, 2 ex., paratypes, 78.5-196.9 $\mathrm{mm} L_{\mathrm{S}}$; Laos: Khammouan Province, Nam Theun, immediately upriver of confluence with Nam Ong; $17^{\circ} 43^{\prime} 00^{\prime \prime} \mathrm{N}$; $105^{\circ} 16^{\prime} 20^{\prime \prime} \mathrm{E}$. ZRC 43393, 2 ex., paratypes, 93.9-96.8 $\mathrm{mm} L_{\mathrm{S}}$; Laos: Nam Theun watershed, Nam Ngouang at Ban Sensi.

P. wynaadensis: AMS B7990, 1 ex., syntype, $129 \cdot 0 \mathrm{~mm} L_{\mathrm{S}}$; India; Tamil Nadu state, Wynaad.

Data on P. afghana is from Kobayakawa (1989), P. burmanensis from Khin Thant (1966), P. furnessi from Bornbusch (1991) and P. morehensis from Arun Kumar \& Tombi Singh (1997).

We thank the following for permission to examine material under their care: $M$. Stiassny and B. Brown (AMNH), M. McGrouther (AMS), D. Siebert (BMNH), D. Catania (CAS), G. Duhamel (MNHN), S. Kullander and E. Ahlander (NRM), L. Parenti (USNM), D. Y. Mai (ZMUH), P. Ng (ZRC) and A. K. Karmakar (ZSI). We are also grateful to $\mathrm{M}$. Kottelat (CMK) for the loan of material and critically reviewing the 
manuscript, and W. Rainboth for permission to use maps and critically reviewing the manuscript. The second author thanks D. V. Serov (Russian Academy of Science, Institute of Ecology and Evolution, Moscow) and T. N. Nguyen (Vietnamese-Russian Science and Technological Tropical Center, Ho Chi Minh City) for the logistic support in Vietnam. This study was supported by the Rackham School of Graduate Studies of the University of Michigan to the first author, a short-term visitor grant to the first author from the Smithsonian Institution, the Volkswagenstiftung to the second author, and research grant R-154-000-062-112 from the National University of Singapore to P. Ng.

\section{References}

Arun Kumar, L. \& Tombi Singh, H. (1997). Silurus morehensis, a new species of silurid cat fish (Order: Siluriformes, Family: Siluridae) from Manipur, India. Journal of Freshwater Biology 9, 72-76.

Atoda, K. (1935). The larva of the catfish Parasilurus asotus L. The Science Reports of the Tohoku University, Sendai, Japan. Fourth Series (Biology) 10, 29-32.

Blyth, E. (1860). Report on some fishes received chiefly from the Sitang River and its tributary streams, Tenasserim Provinces. Journal of the Asiatic Society of Bengal 29, 138-174.

Bornbusch, A. H. (1991). Redescription and reclassification of the silurid catfish Apodoglanis furnessi Fowler (Siluriformes: Siluridae), with diagnoses of three intrafamilial silurid subgroups. Copeia 1991, 1070-1084.

Bornbusch, A. H. (1995). Phylogenetic relationships within the Eurasian catfish family Siluridae (Pisces: Siluriformes), with comments on generic validities and biogeography. Zoological Journal of the Linnean Society 115, 1-46. doi:10.1006/ zjls.1995.0032.

Chen, H.-L. (1977). A review of the Chinese Siluridae. Acta Hydrobiologica Sinica 6, 197-218 (in Chinese with English abstract).

Cuvier, G. \& Valenciennes, A. (1839). Histoire Naturelle des Poissons. Tome 14. Paris: Pitois.

Day, F. (1877). The Fishes of India: being a Natural History of the Fishes known to inhabit the Seas and Freshwaters of India, Burma and Ceylon. Part iii. London: William Dawson \& Sons.

Günther, A. (1864). Catalogue of Fishes in the British Museum. Vol. 5. London: Trustees of the British Museum.

Haig, J. (1952). Studies on the classification of the catfishes of the Oriental and Palaearctic family Siluridae. Records of the Indian Museum 48, 59-116.

Herre, A. W. C. T. (1933). Herklotsella anomala - a new fresh water cat-fish from Hong Kong. Hong Kong Naturalist 4, 179-180.

Hora, S. L. (1936). Siluroid fishes of India, Burma and Ceylon. VI-VIII. Records of the Indian Museum 38, 347-361.

Khin Thant. (1966). Silurus burmanensis, a new species of fish from the Inle Lake, Southern Shan State, Burma. Journal of the Burma Research Society 49, 219-221.

Kobayakawa, M. (1989). Systematic revision of the catfish genus Silurus, with description of a new species from Thailand and Burma. Japanese Journal of Ichthyology 36, 151-186.

Kottelat, M. (1990). Indochinese Nemacheilines. A Revision of Nemacheiline Loaches (Pisces: Cypriniformes) of Thailand, Burma, Laos, Cambodia and Southern Viet Nam. München: Verlag Dr Friedrich Pfeil.

Lim, K. K. P. \& Ng, H. H. (1999). Clarias batu, a new species of catfish (Teleostei: Clariidae) from Pulau Tioman, Peninsular Malaysia. Raffles Bulletin of Zoology, Supplement 6, 157-167.

Mai, Đ. Y. (1978). Định loại cá nuö́c ngọt các tính phía Bác Việt Nam. (Identification of the Fresh-water Fishes of North Vietnam). Hanoi: Nhà Xuât Bán Khoa Hoc Và Kỹ Thuật (in Vietnamese).

Mai, D. Y. (1985). Species composition and distribution of the freshwater fish fauna of the North of Vietnam. Hydrobiologia 121, 281-286. 
Majumdar, N. N. (1951). Notes on Delhi fishes. Journal of the Zoological Society of India 3, 243-247.

Menon, A. G. K. \& Yazdani, G. M. (1968). Catalogue of type-specimens in the Zoological Survey of India. Part 2-Fishes. Records of the Zoological Survey of India 61, 91-190.

Ng, H. H. (1999a). Pterocryptis inusitata, a new species of silurid catfish from Laos (Teleostei: Siluriformes). Ichthyological Exploration of Freshwaters 10, 371-374.

Ng, H. H. (1999b). Two new species of Clarias from Borneo. Raffles Bulletin of Zoology 47, 17-32.

Ng, H. H. \& Kottelat, M. (1998). Pterocryptis buccata, a new species of catfish from western Thailand (Teleostei: Siluridae) with epigean and hypogean populations. Ichthyological Research 45, 393-399.

Ng, H. H. \& Kottelat, M. (1999). Oreoglanis hypsiurus, a new species of glyptosternine catfish (Teleostei: Sisoridae) from Laos. Ichthyological Exploration of Freshwaters 10, 375-380.

Ng, H. H. \& Ng, P. K. L. (2001). A revision of the akysid catfish genus Acrochordonichthys Bleeker. Journal of Fish Biology 58, 386-418. doi:10.1006/ jfbi.2000.1454.

Nguyen, T. T. H. (1999). Dẫn liêu buóc đầu về thành phần loài cá ỏ các sông suối Tây Nguyên. Tạp Chí Sinh Học 21, 26-35 (in Vietnamese).

Orsi, J. J. (1974). A check list of the marine and freshwater fishes of Vietnam. Publications of the Seto Marine Biological Laboratory 21, 153-177.

Peters, W. (1861). Über zwei neue Gattungen von Fischen aus dem Ganges. Monatsberichte der Königlichen Preussischen Akademie des Wissenschaften zu Berlin 1861, 712-713.

Parameswaran, S., Selvaraj, C. \& Radhakrishnam, S. (1971). Notes on the life-history and biology of the catfish Ompok pabda (Hamilton). Journal of the Zoological Society of India 23, 137-150.

Serov, D. V. (1994a). The analysis and distribution of the freshwater ichthyofauna in waters of South Vietnam. In Gidrobionty Iuzhnogo V'etnama: Sbornik Nauchnykh Trudov (Pavlov, D. S. \& Sbikin, IU. N., eds), pp. 17-30. Moscow: Nauka (in Russian with English abstract).

Serov, D. V. (1994b). Polevoi Opredelitel' Presnovodnykh ryb Iuzhnogo V'etnama [Field Identification Guide to the Freshwater Fishes of South Vietnam]. Moscow: Nauka (in Russian).

Soares-Porto, L. M. (1998). Monophyly and interrelationships of the Centromochlinae (Siluriformes: Auchenipteridae). In Phylogeny and Classification of Neotropical Fishes (Malabarba, L. M., Reis, R. E., Vari, R. P., Lucena, Z. M. S. \& Lucena, C. A. S., eds), pp. 331-350. Porto Alegre: EDIPUCRS.

Whitehead, P. J. P. \& Talwar, P. K. (1976). Francis Day (1829-1889) and his collections of Indian fishes. Bulletin of the British Museum (Natural History) Historical Series 5, 1-189.

Xie, X.-J. (1989). On the development of larva of Silurus soldatovi meridionalis Chen. Acta Hydrobiologica Sinica 13, 124-133 (in Chinese with English abstract). 